\title{
A rapid assessment of wastewater for genomic surveillance of SARS-CoV-2 variants at
} sewershed scale in Louisville, $\mathrm{KY}$

Authors

J. L. Fuqua ${ }^{1,2}$, E.C. Rouchka ${ }^{3,4}$, S.Waigel ${ }^{5}$, K. Sokoloski ${ }^{2,6}$, D. Chung ${ }^{2,6}$, W. Zacharias ${ }^{5}$, M. Zhang ${ }^{7}$, J. Chariker ${ }^{3,4}$, D. Talley ${ }^{8}$, I. Santisteban ${ }^{1,2}$, A. Varsani ${ }^{9}$, S. Moyer ${ }^{10,11}$, R. H. Holm ${ }^{12}$, R. A. Yeager $^{12,13}$, T. Smith ${ }^{12}$, A. Bhatnagar ${ }^{12}$

*Corresponding

Affiliations

1. Department of Pharmacology and Toxicology, University of Louisville, 505 S. Hancock St., Louisville, KY 40202, United States

2. Center for Predictive Medicine, University of Louisville, 505 S. Hancock St., Louisville, KY 40202, United States

3. Department of Computer Science and Engineering, University of Louisville, 522 East Gray St., Louisville, KY 40202, United States

4. KY-INBRE Bioinformatics Core, University of Louisville, 522 East Gray St., Louisville, KY 40202, United States

5. Department of Medicine, University of Louisville, 530 S. Hancock Jackson St., Louisville, KY 40402, United States

6. Department of Microbiology and Immunology, University of Louisville, 505 S. Hancock St., Louisville, KY 40202, United States

7. Department of Neuroscience Training, University of Louisville, 505 S. Hancock St, Louisville, KY 40202

8. Louisville/Jefferson County Metropolitan Sewer District, Morris Forman Water Quality Treatment Center, 4522 Algonquin Parkway, Louisville KY 40211, United States

9. The Biodesign Center of Fundamental and Applied Microbiomics, School of Life Sciences, Center for Evolution and Medicine, Arizona State University, Tempe, AZ 85287, United States

10. Department of Health Management and System Sciences, School of Public Health and Information Sciences, University of Louisville, 485 E. Gray St., Louisville, KY 40202, United States

11. Department of Public Health and Wellness, Louisville Metro Government, 400 E. Grays St., Louisville, KY 40202, United States

12. Christina Lee Brown Envirome Institute, University of Louisville, $302 \mathrm{E}$. Muhammad Ali Blvd., Louisville, KY 40202, United States

13. Department of Environmental and Occupational Health Sciences, School of Public Health and Information Sciences, University of Louisville, 485 E. Gray St., Louisville, KY 40202, United States 
medRxiv preprint doi: https://doi.org/10.1101/2021.03.18.21253604; this version posted March 26, 2021. The copyright holder for this preprint (which was not certified by peer review) is the author/funder, who has granted medRxiv a license to display the preprint in perpetuity.

It is made available under a CC-BY 4.0 International license .

\section{Abstract}

45

46 In this communication, we report on the genomic surveillance of SARS-CoV-2 using wastewater

47 samples in Jefferson County, KY. In February 2021, we analyzed seven wastewater samples for

48 SARS-CoV-2 genomic surveillance. Variants observed in smaller catchment areas, such as

49 neighborhood manhole locations, were not necessarily consistent when compared to

50 associated variant results in downstream treatment plants, suggesting catchment size or

51 population could impact the ability to detect diversity.

52 
medRxiv preprint doi: https://doi.org/10.1101/2021.03.18.21253604; this version posted March 26, 2021. The copyright holder for this preprint (which was not certified by peer review) is the author/funder, who has granted medRxiv a license to display the preprint in perpetuity.

It is made available under a CC-BY 4.0 International license .

The successful viral detection of severe acute respiratory syndrome coronavirus 2 (SARS-

54 CoV-2) RNA in wastewater at various pooled scales (1-4) and discovery in the USA of B.1.1.7,

B.1.351 and P.1 variants (5), has led to an interest in developing reliable population-level wastewater viral genomic surveillance.

The diversity of SARS-CoV-2 sequences reported to be circulating in the USA, have been determined by sequencing clinical samples; however, these variants can also be surveilled by

59 sequencing wastewater samples (6-9). As of March 2021, the variants of concern - B.1.1.7, could indicate incomplete surveillance. Broadening the application of genomic surveillance using wastewater in the community could enhance SARS-CoV-2 variant population monitoring. wastewater samples in Jefferson County, KY. Samples were collected from manholes and treatment facilities, covering populations of 8,000 to 350,000 people (Table 1 ). RNA isolated

67 from wastewater samples was used to quantify SARS-CoV-2 and analyze the genetic variation through high-throughput sequencing (See Supplementary Methods). Bioinformatics approaches

69 were used to rapidly identify single nucleotide genetic alterations, which were compared with

70 known variants of interest and concern.

72 surveillance (Figure 1). We did not detect genetic variations indicative of any current variant of

73 concern, beyond the widespread D614G spike protein mutation (Supplementary Methods

74 Tables 2-5). In all samples, we identified at least four of ten mutations consistent with the 
medRxiv preprint doi: https://doi.org/10.1101/2021.03.18.21253604; this version posted March 26, 2021. The copyright holder for this preprint (which was not certified by peer review) is the author/funder, who has granted medRxiv a license to display the preprint in perpetuity.

It is made available under a CC-BY 4.0 International license .

75 presence of the variant of interest B.1.429, and one sample contained seven of ten mutations

76 (Table 2). The B.1.429 variant was confirmed in patient samples in Kentucky in January 2021

77 (10), and a single patient in the study area was reported to be positive for B.1.1.7 on February

789,2021 (11). With our current metrics we flagged sites 833, 891, and Treatment plant \#2 for

79 potential presence of variant B.1.429 (3/7 sites). Differences in the scale of sample pooling in

80 the community revealed unanticipated inconsistencies in variant representation. Specifically,

81 variants observed in smaller catchment areas, such as neighborhood manhole locations, were

82 not observed in downstream treatment plants, suggesting catchment size or population could

83 impact the ability to detect diversity.

84 Given the highly variable viral genome sequence coverage recovered from wastewater

85 samples, there is an urgent need to develop a set of consistent thresholds constituting

86 positive/negative presence of a variant. Monitoring SARS-CoV-2 variants in wastewater may

87 warn of an emerging variant of concern and identify variant dominance occurring when a new

88 variant is introduced in a community. Wastewater genetic monitoring may be particularly

89 useful in the context of limited clinical sample sequencing capacity because a broad perspective

90 on the genetic diversity can be obtained from a few samples. To develop comprehensive

91 epidemiological frameworks required to guide policy, population-level wastewater surveillance

92 of viral genetic diversity should be complemented by clinical sample testing.

93

94

95

96

97

98

99 
medRxiv preprint doi: https://doi.org/10.1101/2021.03.18.21253604; this version posted March 26, 2021. The copyright holder for this preprint (which was not certified by peer review) is the author/funder, who has granted medRxiv a license to display the preprint in perpetuity.

It is made available under a CC-BY 4.0 International license .

\section{References}

1. Betancourt WW, et al. (2020) Wastewater-based Epidemiology for Averting COVID-19 Outbreaks on The University of Arizona Campus. medRxiv:2020.2011.2013.20231340.

2. Wu F, et al. (2020) SARS-CoV-2 Titers in Wastewater Are Higher than Expected from Clinically Confirmed Cases. mSystems 5(4).

3. Weidhaas J, et al. (2021) Correlation of SARS-CoV-2 RNA in wastewater with COVID-19 disease burden in sewersheds. Sci Total Environ 775:145790.

4. Yeager RA, et al. (2020) Wastewater sample site selection to estimate geographically-

Acknowledgments: This project was supported by funding from Louisville Metro Public Health and Wellness. Part of this work was performed with assistance of the UofL Genomics Facility, which was supported by NIH/NIGMS KY-INBRE P20GM103436, the J.G. Brown Cancer Center, University of Louisville, and user fees. The following reagent was deposited by the Centers for Disease Control and Prevention and obtained through BEI Resources, NIAID, NIH: Quantitative PCR (qPCR) Control RNA from Heat-Inactivated SARS-Related Coronavirus 2, Isolate USAWA1/2020, NR 52347.

Ethics: The University of Louisville Institutional Review Board classified this project as NonHuman Subjects Research (NHSR) (reference \#: 717950). 
medRxiv preprint doi: https://doi.org/10.1101/2021.03.18.21253604; this version posted March 26, 2021. The copyright holder for this preprint (which was not certified by peer review) is the author/funder, who has granted medRxiv a license to display the preprint in perpetuity.

It is made available under a CC-BY 4.0 International license.

\section{FIGURE LEGENDS}

Fig.1 Distribution of the sewershed area, treatment plants and community locations, in Jefferson County with corresponding dates, sampled. SARS-CoV-2 was detected at all sites. Samples that contained at least $50 \%$ of the single amino acid mutations for a variant with a nucleotide frequency above a $5 \%$ threshold for individual mutations are flagged for review. This relatively low threshold serves the purpose of identifying geographic (sewershed) areas for heightened public health surveillance. With our current metrics we flagged sites 833,891 , and Treatment plant \#2 for potential presence of variant B.1.429.

Table 1. Summary of wastewater SARS-CoV-2 samples sequenced in this study, Louisville, KY

\begin{tabular}{|c|c|c|c|c|}
\hline Sample ID & $\begin{array}{l}\text { Sewershed } \\
\text { population }\end{array}$ & Location & N1 (Ct) & $\begin{array}{l}\text { Sequencing BWA } \\
\text { Alignment Rate (\%) }\end{array}$ \\
\hline 833 & 35,956 & $\begin{array}{c}\text { Street line manhole } \\
\text { leading to Treatment } \\
\text { Plant } \# 3^{a}\end{array}$ & 28 & 28.02 \\
\hline $\begin{array}{l}\text { Treatment } \\
\text { Plant \#1 }\end{array}$ & 55,928 & Treatment Plant & 30 & 21.09 \\
\hline 847 & 10,739 & $\begin{array}{c}\text { Street line manhole } \\
\text { leading to Treatment } \\
\text { Plant \#2 }\end{array}$ & 29 & 15.08 \\
\hline 849 & 35,956 & $\begin{array}{c}\text { Street line manhole } \\
\text { leading to Treatment } \\
\text { Plant } \# 3^{a}\end{array}$ & 28 & 12.61 \\
\hline 884 & 46,659 & $\begin{array}{c}\text { Street line manhole } \\
\text { leading to Treatment } \\
\text { Plant } \# 3^{a}\end{array}$ & 29 & 23.98 \\
\hline 891 & 8,071 & $\begin{array}{c}\text { Street line manhole } \\
\text { leading to Treatment } \\
\text { Plant \#2 }\end{array}$ & 29 & 26.03 \\
\hline $\begin{array}{l}\text { Treatment } \\
\text { Plant \#2 }\end{array}$ & 349,850 & Treatment Plant & 31 & 19.96 \\
\hline
\end{tabular}

a Treatment Plant \#3 samples had SARS-CoV-2 was detected but were below the threshold for individual mutations for review.

Table 2. Summary of B.1.429 specific mutation prevalence by sample

\begin{tabular}{|c|c|c|c|c|c|c|c|c|c|c|c|}
\hline $\begin{array}{l}\text { Ref } \\
\text { Pos }\end{array}$ & Gene/ORF & $\begin{array}{c}\text { Ref } \\
\text { Allele }\end{array}$ & $\begin{array}{c}\text { Alt } \\
\text { Allele }\end{array}$ & $\begin{array}{c}\text { Variant } \\
\text { Desc }\end{array}$ & 833 & $\begin{array}{c}\text { Treatment } \\
\text { Plant \#1 }\end{array}$ & 847 & 849 & 884 & 891 & $\begin{array}{c}\text { Treatment } \\
\text { Plant \#2 }\end{array}$ \\
\hline 1059 & ORF1ab1 & $\mathrm{C}$ & $T$ & T265I & 0.9309 & 0.8798 & 0.9823 & 0.8906 & 0.9844 & 0.9773 & 0.7382 \\
\hline 12878 & ORF1ab1 & $A$ & $\mathrm{G}$ & $14205 \mathrm{~V}$ & 0.2084 & 0 & 0 & 0.0015 & 0 & 0.0504 & 0.9968 \\
\hline 14408 & ORF1ab2 & $C$ & $\mathrm{~T}$ & P314L & 1 & 1 & 0.9975 & 1 & 0.909 & 0.8757 & 0.8537 \\
\hline 17014 & ORF1ab2 & $\mathrm{G}$ & $\mathrm{T}$ & D1183Y & 0.049 & 0.0051 & 0 & 0.025 & 0.0024 & 0.0026 & 0.0027 \\
\hline 21600 & $S$ & $\mathrm{G}$ & $T$ & S13I & 0 & 0 & 0 & 0 & 0 & 0.0025 & 0 \\
\hline 22018 & $S$ & G & $\mathrm{T}$ & W152C & 0.1287 & 0 & 0 & 0 & 0.002 & 0.0022 & 0.0016 \\
\hline 22917 & $\mathrm{~S}$ & $\mathrm{~T}$ & $\mathrm{G}$ & L452R & 0.1297 & 0 & 0 & 0 & 0 & 0 & 0 \\
\hline 23403 & $\mathrm{~S}$ & A & $\mathrm{G}$ & D614G & 0.9972 & 1 & 0.9969 & 1 & 0.9969 & 0.9977 & 0.9981 \\
\hline 25563 & ORF3a & $\mathrm{G}$ & $\mathrm{T}$ & Q57H & 0.9893 & 0.6967 & 0.9621 & 0.9987 & 0.8682 & 0.7933 & 0.4046 \\
\hline 28887 & $\mathrm{~N}$ & $\mathrm{C}$ & $T$ & T205I & 0.0422 & 0.0426 & 0 & 0.0017 & 0 & 0 & 0 \\
\hline
\end{tabular}


medRxiv preprint doi: https://doi.org/10.1101/2021.03.18.21253604; this version posted March 26, 2021. The copyright holder for this preprint (which was not certified by peer review) is the author/funder, who has granted medRxiv a license to display the preprint in perpetuity.

It is made available under a CC-BY 4.0 International license .

Figure 1. Study sites within Louisville, KY

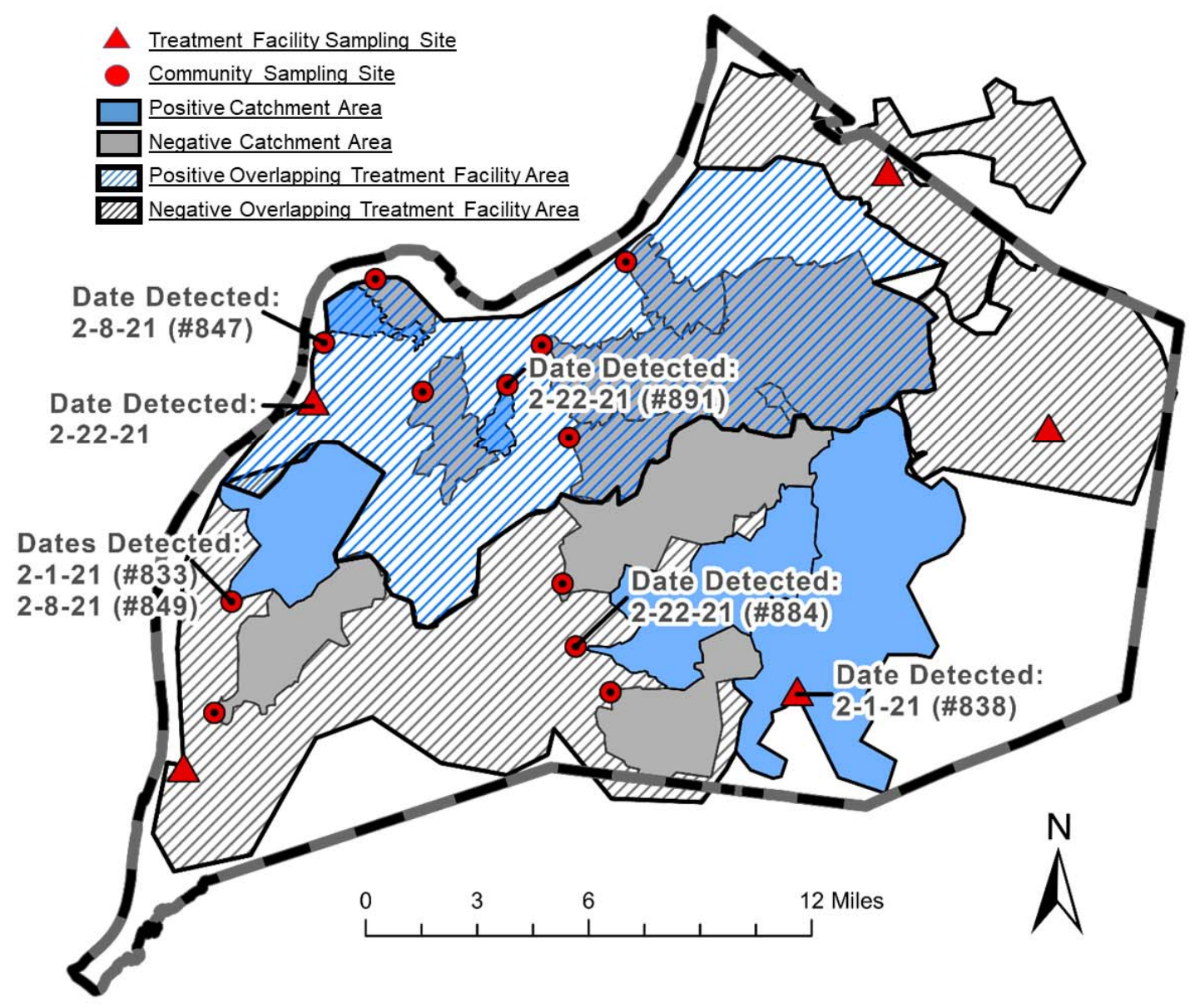


medRxiv preprint doi: https://doi.org/10.1101/2021.03.18.21253604; this version posted March 26, 2021. The copyright holder for this preprint (which was not certified by peer review) is the author/funder, who has granted medRxiv a license to display the preprint in perpetuity.

It is made available under a CC-BY 4.0 International license .

\section{Supplementary Methods}

Wastewater sample Prep

Wastewater samples were collected on February 1, 8 and 22, 2021. In brief, a 24-hour composite raw wastewater sample was collected into a sterile $125 \mathrm{ml}$ polyethylene terephthalate bottle. Viral particles where concentrated using PEG precipitation methods. For each sample, $40 \mathrm{ml}$ of chilled wastewater was passed through a $70 \mu \mathrm{m}$ cell strainer and PEG 8000 and $(0.5 \mathrm{~g}) \mathrm{NaCl}$ were added to a final concentration of $12.5 \mathrm{mM}$ and $210 \mathrm{mM}$, respectively. Samples were refrigerated overnight at $4^{\circ} \mathrm{C}$ and then centrifuged at $16,000 \times \mathrm{g}$ for $30 \mathrm{mins}$ at $4^{\circ} \mathrm{C}$. The pellet was resuspended with $1.1 \mathrm{ml} \mathrm{TRIzol}$ (Thermo Scientific \# 15596018) and transferred to a sterile microfuge tube. The TRIzol sample was then incubated for 5 mins at room temperature and then centrifuged at $12,000 \times \mathrm{g}$ for $5 \mathrm{~min}$ at $4^{\circ} \mathrm{C}$. The sample was then divided into two $500 \mu \mathrm{l}$ samples, one for isolation and one for archiving at $-80^{\circ} \mathrm{C}$. The sample for isolation had an additional $500 \mu$ l of TRIzol added and $900 \mu$ of $100 \%$ Ethanol. Samples were

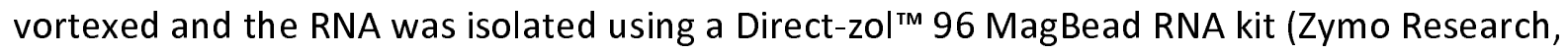
R2102) with RNA eluted in 100 $\mu$ l of DNAse/RNAse Free Water. RNA cleanup was done using the RNeasy ${ }^{\circledR}$ PowerClean ${ }^{\circledR}$ Pro Cleanup Kit (Qiagen \#13995-50) according to the manufacturer's instructions with RNA eluted in $60 \mu$ l of DNAse/RNAse Free Water. Purified RNA was inspected for yield and quality using a NanoDrop 1000. Number of viral copies in each sample was determined using a probe-based RT-qPCR on a QuantStudio 3 (Applied Biosystems) real-time PCR system using Taq 1-Step Multiplex Master Mix (Thermo Fisher \#A28527). The primer and probe sequences are shown in Table 1 with 5 primer/probe sets used for each sample and all samples ran in triplicate. $4 \mu \mathrm{l}$ of sample was used for each $20 \mu \mathrm{l}$ reaction. PCR cycling conditions were $25^{\circ} \mathrm{C}$ for $2 \mathrm{~min}, 50^{\circ} \mathrm{C}$ for $10 \mathrm{mins}, 95^{\circ} \mathrm{C}$ for $2 \mathrm{~min}$ and 45 cycles of $95^{\circ} \mathrm{C}$ for $2 \mathrm{sec}$ and $60^{\circ} \mathrm{C}$ for $30 \mathrm{sec}$. We generated a standard curve for each primer-probe set used and fit the $\mathrm{Ct}$ values to extrapolate copies per $\mathrm{mL}$ of wastewater. For this publication we are only reporting on the $\mathrm{N} 1 \mathrm{Ct}$ values generated from this methodology.

\section{CDNA Synthesis}

The Superscript ${ }^{\circledR}$ IV First-Strand Synthesis System (Thermo Fisher \#18091050) was used to generate cDNA with random hexamer primers. The RT reaction was mixed according to manufacturer's instructions with a final reaction volume of $20 \mu \mathrm{l}$ and $5 \mu \mathrm{l}$ of our template RNA added to the mixture. The reverse transcriptase incubation step was performed with sequential incubation at $23^{\circ} \mathrm{C}$ for $10 \mathrm{~min}, 50^{\circ} \mathrm{C}$ for $30 \mathrm{~min}$, and $80^{\circ} \mathrm{C}$ for $10 \mathrm{~min}$, according to the manufacturer's protocol with adjustment of the incubation times recommended by Swift Biosciences SNAP low input protocol.

\section{Library Prep}

Libraries were prepared using the Swift Biosciences SNAP low input protocol for SARS-CoV-2 (Swift Bioscience, Ann Arbor, MI, Cat \# COSG1V2-96, SN-5X296). $10 \mu$ l of cDNA was combined with $20 \mu$ l of reaction mix and proceeded with multiplex PCR according to protocol. The PCR product was cleaned up using SPRIselect beads (Beckman Coulter, Brea, CA, Cat. No. B23318) at a 1.0X ratio. The purified sample/beads mix was resuspended in $17.4 \mu \mathrm{l}$ of TE buffer provided in the post-PCR kit. Samples were indexed through PCR with the SNAP Unique Dual Indexing Primers (Swift Bioscience, Ann Arbor, Cat. \# SN91096-1-PLATE). The indexing PCR product was 
medRxiv preprint doi: https://doi.org/10.1101/2021.03.18.21253604; this version posted March 26, 2021. The copyright holder for this preprint (which was not certified by peer review) is the author/funder, who has granted medRxiv a license to display the preprint in perpetuity.

It is made available under a CC-BY 4.0 International license .

further cleaned up and eluted from the beads using a 0.65X PEG NaCl clean-up. The purified libraries were then eluted in $22 \mu \mathrm{L}$ of TE buffer and transferred to fresh tubes and stored at $20^{\circ} \mathrm{C}$. For some of the samples $(884,891$, and Treatment Plant \#2), 1 additional cycle was added to the multiplex PCR and 2 additional cycles were added to the indexing PCR to obtain higher library yields. The library concentration was measured using the Qubit dsDNA HS Assay Kit (Thermo Fisher, Waltham, MA, Q32851). The libraries' size distribution was checked on the Agilent Bioanalyzer using the DNA High Sensitivity Kit (Agilent Technologies, Cat\# 5067-4626). Library normalization was performed according to SwiftBio's Normalase 2nM final pool protocol. $5 \mu \mathrm{l}$ of Normalase I Master Mix were added to each 20 $\mu$ l library eluate for a final pool of $2 \mathrm{nM}$ and thoroughly mixed. Samples were placed in the thermocycler to incubate at $30^{\circ} \mathrm{C}$ for $15 \mathrm{~min} .5 \mu \mathrm{l}$ of each library were pooled, and $1 \mu \mathrm{l}$ of Normalase II Master Mix per library was added and thoroughly mixed. The library pool was placed in the thermocycler to incubate at $37^{\circ} \mathrm{C}$ for $15 \mathrm{~min} .0 .2 \mu \mathrm{l}$ of Reagent $\mathrm{X} 1$ per library was added to the pool to inactivate Normalase II at $95^{\circ} \mathrm{C}$ for $2 \mathrm{~min}$ and held at $4^{\circ} \mathrm{C}$.

\section{Sequencing}

Library pool and PhiX were denatured and diluted following Illumina's directions. Libraries with $1 \%$ PhiX spike-in were sequenced at read length $2 \times 150$ bp using the MiSeq Reagent Kit v2 300 cycle (Illumina, San Diego, CA, Cat\# MS-102-2002), or the NextSeq 500/550 Mid Output Kit v2.5 300 Cycles (Illumina, San Diego, CA, Cat\# 20024905), targeting 1-5 M reads per library.

\section{Data analysis}

Sequencing reads were analyzed using a custom bioinformatics pipeline. Low quality bases were trimmed using Trimmomatic v0.38 (1), and were then aligned to the NC_045512.2 reference genome using bwa mem v 0.7.17-r1188 (2). Single nucleotide variants (SNVs) relative to the reference were detected using bcftools mpileup (3). SNVs occurring in at least $5 \%$ of the reads with at least five separate supporting instances were marked for further interrogation. SNVs occurring at locations of interest as they relate to specific SARS-CoV-2 variants (B.1.1.7, B.1.351, B.1.526, P.1, and B.1.429) were reported for all of the samples (Supplementary Methods Tables 2-5).

Table 1. Primer and probe sequences used for RT-qPCR

\begin{tabular}{|l|l|l|}
\hline Primer Name & Sequence & Probes \\
\hline 2019-nCoV_N1-F & 5'-GACCCCAAAATCAGCGAAAT-3' & None \\
\hline 2019-nCoV_N1-R & 5'-TCTGGTTACTGCCAGTTGAATCTG-3' & None \\
\hline 2019-nCoV_N1-P & 5'-FAM-ACCCCGCATTACGTTTGGTGGACC-QSY-3' & FAM, BHQ-1 \\
\hline RNase P-F & 5'-AGATTTGGACCTGCGAGCG-3' & None \\
\hline RNase P-R & 5'-GAGCGGCTGTCTCCACAAGT-3' & None \\
\hline RNase P-P & 5'-JUN-TTCTGACCTGAAGGCTCTGCGCG-QSY-3' & JUN, BHQ-1 \\
\hline CoV_ORF1ab-F & 5'-GTCGTAGTGGTGAGACACTTG-3' & None \\
\hline
\end{tabular}


medRxiv preprint doi: https://doi.org/10.1101/2021.03.18.21253604; this version posted March 26, 2021. The copyright holder for this preprint (which was not certified by peer review) is the author/funder, who has granted medRxiv a license to display the preprint in perpetuity.

It is made available under a CC-BY 4.0 International license .

\begin{tabular}{|l|l|l|}
\hline COV_ORF1ab-R & 5'-GGCCACCAGCTCCTTATTA-3' & None \\
\hline CoV_ORF1ab-P & 5'-FAM-ATACCAGTGGCTTACCGCAAGGTT-QSY-3' & FAM, BHQ-1 \\
\hline PMMoV-F & 5'-GAGTGGTTTGACCTTAACGTTTGA-3' & None \\
\hline PMMoV-R & 5'-TGTCGGTTGCAATGCAAGT-3' & None \\
\hline PMMoV-P & 5'-VIC-CCTACCGAAGCAAATG-QSY-3' & VIC, BHQ-1 \\
\hline CrAssphage-F & 5'-CAGAAGTACAAACTCCTAAAAAACGTAGAG-3' & None \\
\hline CrAssphage-R & 5'-GATGACCAATAAACAAGCCATTAGC-3' & None \\
\hline CrAssphage-P & 5'-JUN-AATAACGATTTACGTGATGTAAC-QSY-3' & JUN, BHQ-1 \\
\hline
\end{tabular}

Table 2. Summary of B.1.1.7 specific mutation prevalence by sample

\begin{tabular}{|c|c|c|c|c|c|c|c|c|c|c|c|}
\hline $\begin{array}{l}\text { Ref } \\
\text { Pos }\end{array}$ & Gene/ORF & $\begin{array}{c}\text { Ref } \\
\text { Allele }\end{array}$ & $\begin{array}{c}\text { Alt } \\
\text { Allele }\end{array}$ & $\begin{array}{c}\text { Variant } \\
\text { Desc }\end{array}$ & 833 & $\begin{array}{c}\text { Treatment } \\
\text { Plant \#1 }\end{array}$ & 847 & 849 & 884 & 891 & $\begin{array}{r}\text { Treatmen } \\
\text { Plant \#2 }\end{array}$ \\
\hline 3267 & ORF1ab1 & $\mathrm{C}$ & $\mathrm{T}$ & T1001I & 0 & 0.0008 & 0 & 0 & 0 & 0 & 0 \\
\hline 5388 & ORF1ab1 & $\mathrm{C}$ & $A$ & A1708D & 0.0015 & 0 & 0 & 0 & 0.0016 & 0.0019 & 0.0016 \\
\hline 6954 & ORF1ab1 & $\mathrm{T}$ & $\mathrm{C}$ & I2230T & 0 & 0 & 0 & 0 & 0 & 0 & 0 \\
\hline 11288 & ORF1ab1 & $T$ & $\langle *\rangle$ & S3675DEL & 0 & 0 & 0 & 0 & 0 & 0 & 0 \\
\hline 11289 & ORF1ab1 & $\mathrm{C}$ & $\langle *\rangle$ & S3675DEL & 0 & 0 & 0 & 0 & 0 & 0 & 0 \\
\hline 11290 & ORF1ab1 & $\mathrm{T}$ & $\langle *\rangle$ & S3675DEL & 0 & 0 & 0 & 0 & 0 & 0 & 0 \\
\hline 11291 & ORF1ab1 & $\mathrm{G}$ & $\langle *\rangle$ & G3676DEL & 0 & 0 & 0 & 0 & 0 & 0 & 0 \\
\hline 11292 & ORF1ab1 & G & $\langle *\rangle$ & G3676DEL & 0 & 0 & 0 & 0 & 0 & 0 & 0 \\
\hline 11293 & ORF1ab1 & $T$ & $\langle *\rangle$ & G3676DEL & 0 & 0 & 0 & 0 & 0 & 0 & 0 \\
\hline 11294 & ORF1ab1 & $T$ & $\langle *\rangle$ & F3677DEL & 0 & 0 & 0 & 0 & 0 & 0 & 0 \\
\hline 11295 & ORF1ab1 & $\mathrm{T}$ & $\langle *\rangle$ & F3677DEL & 0 & 0 & 0 & 0 & 0 & 0 & 0 \\
\hline 11296 & ORF1ab1 & $T$ & $\langle *\rangle$ & F3677DEL & 0 & 0 & 0 & 0 & 0 & 0 & 0 \\
\hline 21767 & $\mathrm{~S}$ & $C$ & $\langle *\rangle$ & H69DEL & 0 & 0 & 0 & 0 & 0 & 0 & 0 \\
\hline 21768 & $S$ & A & $\langle *\rangle$ & H69DEL & 0 & 0 & 0 & 0 & 0 & 0 & 0 \\
\hline 21769 & $\mathrm{~S}$ & $T$ & $\langle *\rangle$ & H69DEL & 0 & 0 & 0 & 0 & 0 & 0 & 0 \\
\hline 21770 & $S$ & $\mathrm{G}$ & $\langle *\rangle$ & H7ODEL & 0 & 0 & 0 & 0 & 0 & 0 & 0 \\
\hline 21771 & $S$ & $T$ & $\langle *\rangle$ & H7ODEL & 0 & 0 & 0.0494 & 0 & 0 & 0 & 0 \\
\hline 21772 & $\mathrm{~S}$ & $\mathrm{C}$ & $\langle *\rangle$ & H7ODEL & 0 & 0 & 0 & 0 & 0 & 0 & 0 \\
\hline 21992 & $S$ & $T$ & $\langle *\rangle$ & Y144DEL & 0 & 0 & 0 & 0 & 0 & 0 & 0 \\
\hline 21993 & $S$ & A & $\langle *\rangle$ & Y144DEL & 0 & 0 & 0 & 0 & 0 & 0 & 0 \\
\hline 21994 & $\mathrm{~S}$ & $T$ & $\langle *\rangle$ & Y144DEL & 0.0404 & 0 & 0 & 0 & 0 & 0 & 0 \\
\hline 23063 & $S$ & A & $\mathrm{T}$ & N501Y & 0 & 0 & 0 & 0 & 0.0029 & 0.0038 & 0.0044 \\
\hline 23271 & $S$ & $\mathrm{C}$ & $\mathrm{A}$ & A570D & 0 & 0 & 0 & 0 & 0.0023 & 0.0021 & 0.0023 \\
\hline 23403 & $\mathrm{~S}$ & A & $\mathrm{G}$ & D614G & 0.9972 & 1 & 0.9969 & 1 & 0.9969 & 0.9977 & 0.9981 \\
\hline 23604 & $\mathrm{~S}$ & $\mathrm{C}$ & $A$ & $\mathrm{P} 681 \mathrm{H}$ & 0.0013 & 0.0671 & 0 & 0 & 0.0645 & 0.002 & 0.169 \\
\hline 23709 & $\mathrm{~S}$ & $\mathrm{C}$ & $\mathrm{T}$ & 77161 & 0.0006 & 0.0007 & 0 & 0.0029 & 0.0003 & 0 & 0.0064 \\
\hline 24506 & $\mathrm{~S}$ & $T$ & $\mathrm{G}$ & S982A & 0 & 0 & 0 & 0 & 0 & 0 & 0 \\
\hline 24914 & $S$ & G & $C$ & $\mathrm{D} 1118 \mathrm{H}$ & 0 & 0 & 0 & 0 & 0 & 0 & 0 \\
\hline 27972 & ORF8 & $\mathrm{C}$ & $\langle *\rangle$ & Q27* & 0 & 0 & 0 & 0 & 0 & 0 & 0 \\
\hline 28048 & ORF8 & $A$ & $\mathrm{G}$ & $Y 73 \mathrm{C}$ & 0 & 0 & 0 & 0 & 0 & 0 & 0 \\
\hline 28280 & $\mathrm{~N}$ & G & $C$ & D3L & 0 & 0 & 0 & 0 & 0 & 0 & 0 \\
\hline 28281 & $\mathrm{~N}$ & A & $T$ & D3L & 0 & 0 & 0 & 0 & 0.0009 & 0.002 & 0.002 \\
\hline 28977 & $\mathrm{~N}$ & $\mathrm{C}$ & $T$ & S235F & 0.0013 & 0.0039 & 0 & 0.0029 & 0 & 0.0013 & 0 \\
\hline
\end{tabular}


medRxiv preprint doi: https://doi.org/10.1101/2021.03.18.21253604; this version posted March 26, 2021. The copyright holder for this preprint (which was not certified by peer review) is the author/funder, who has granted medRxiv a license to display the preprint in perpetuity.

It is made available under a CC-BY 4.0 International license .

Table 3. Summary of B.1.351 specific mutation prevalence by sample

\begin{tabular}{|c|c|c|c|c|c|c|c|c|c|c|c|}
\hline $\begin{array}{c}\text { Ref } \\
\text { Pos }\end{array}$ & Gene/ORF & $\begin{array}{c}\text { Ref } \\
\text { Allele }\end{array}$ & $\begin{array}{c}\text { Alt } \\
\text { Allele }\end{array}$ & $\begin{array}{c}\text { Variant } \\
\text { Desc }\end{array}$ & $\mathbf{8 3 3}$ & $\begin{array}{c}\text { Treatment } \\
\text { Plant \#1 }\end{array}$ & $\mathbf{8 4 7}$ & $\mathbf{8 4 9}$ & $\mathbf{8 8 4}$ & $\mathbf{8 9 1}$ & $\begin{array}{c}\text { Treatment } \\
\text { Plant \#2 }\end{array}$ \\
\hline 5230 & ORF1ab1 & G & T & K1655N & 0.0006 & 0 & 0 & 0.0014 & 0.0023 & 0.0022 & 0.0021 \\
\hline 22813 & S & G & C & K417N & 0 & 0 & 0 & 0 & 0 & 0 & 0 \\
\hline 23012 & S & G & A & E484K & 0 & 0 & 0 & 0 & 0 & 0 & 0 \\
\hline 23063 & S & A & T & N501Y & 0 & 0 & 0 & 0 & 0.0029 & 0.0038 & 0.0044 \\
\hline 23403 & S & A & G & D614G & $\mathbf{0 . 9 9 7 2}$ & 1 & $\mathbf{0 . 9 9 6 9}$ & 1 & $\mathbf{0 . 9 9 6 9}$ & $\mathbf{0 . 9 9 7 7}$ & $\mathbf{0 . 9 9 8 1}$ \\
\hline 23664 & S & C & T & A701V & 0 & 0.0018 & 0.0051 & 0.0035 & 0.0009 & 0 & 0 \\
\hline 26456 & E & C & T & P71L & 0 & 0.0069 & 0 & 0 & 0 & 0 & 0 \\
\hline 28887 & N & C & T & T205I & 0.0422 & 0.0426 & 0 & 0.0017 & 0 & 0 & 0 \\
\hline
\end{tabular}

Table 4. Summary of B.1.526 specific mutation prevalence by sample

\begin{tabular}{|c|c|c|c|c|c|c|c|c|c|c|c|}
\hline $\begin{array}{c}\text { Ref } \\
\text { Pos }\end{array}$ & Gene/ORF & $\begin{array}{c}\text { Ref } \\
\text { Allele }\end{array}$ & $\begin{array}{c}\text { Alt } \\
\text { Allele }\end{array}$ & $\begin{array}{c}\text { Variant } \\
\text { Desc }\end{array}$ & $\mathbf{8 3 3}$ & $\begin{array}{c}\text { Treatment } \\
\text { Plant \#1 }\end{array}$ & $\mathbf{8 4 7}$ & $\mathbf{8 4 9}$ & $\mathbf{8 8 4}$ & $\mathbf{8 9 1}$ & $\begin{array}{c}\text { Treatment } \\
\text { Plant \#2 }\end{array}$ \\
\hline 21575 & S & C & T & L5F & 0 & 0 & 0.0051 & 0 & 0 & 0.011 & 0 \\
\hline 21846 & S & C & T & T95I & 0 & 0 & 0 & 0 & 0 & 0 & 0 \\
\hline 22320 & S & A & G & D253G & 0 & 0 & 0 & 0 & 0 & 0 & 0 \\
\hline 23012 & S & G & A & E484K & 0 & 0 & 0 & 0 & 0 & 0 & 0 \\
\hline 23403 & S & A & G & D614G & $\mathbf{0 . 9 9 7 2}$ & 1 & $\mathbf{0 . 9 9 6 9}$ & 1 & $\mathbf{0 . 9 9 6 9}$ & $\mathbf{0 . 9 9 7 7}$ & $\mathbf{0 . 9 9 8 1}$ \\
\hline 23664 & S & C & T & A701V & 0 & 0.0018 & 0.0051 & 0.0035 & 0.0009 & 0 & 0 \\
\hline
\end{tabular}

Table 5. Summary of P.1 specific mutation prevalence by sample

\begin{tabular}{|c|c|c|c|c|c|c|c|c|c|c|c|}
\hline $\begin{array}{l}\text { Ref } \\
\text { Pos }\end{array}$ & Gene/ORF & $\begin{array}{c}\text { Ref } \\
\text { Allele }\end{array}$ & $\begin{array}{c}\text { Alt } \\
\text { Allele }\end{array}$ & $\begin{array}{l}\text { Variant } \\
\text { Desc }\end{array}$ & 833 & $\begin{array}{c}\text { Treatment } \\
\text { Plant \#1 }\end{array}$ & 847 & 849 & 884 & 891 & $\begin{array}{c}\text { Treatment } \\
\text { Plant \#2 }\end{array}$ \\
\hline 2308 & ORF1ab1 & $\mathrm{T}$ & $A$ & L681L & 0 & 0 & 0.0008 & 0 & 0 & 0.0012 & 0.0003 \\
\hline 2545 & ORF1ab1 & $\mathrm{T}$ & $\mathrm{G}$ & T760T & 0 & 0.0008 & 0 & 0 & 0 & 0 & 0 \\
\hline 3828 & ORF1ab1 & $\mathrm{C}$ & $T$ & S1188L & 0 & 0 & 0 & 0 & 0 & 0 & 0 \\
\hline 5648 & ORF1ab1 & A & $C$ & K1795Q & 0 & 0 & 0 & 0.0011 & 0 & 0 & 0 \\
\hline 11288 & ORF1ab1 & $\mathrm{T}$ & $\langle *\rangle$ & S3675DEL & 0 & 0 & 0 & 0 & 0 & 0 & 0 \\
\hline 11289 & ORF1ab1 & $\mathrm{C}$ & $\langle *\rangle$ & S3675DEL & 0 & 0 & 0 & 0 & 0 & 0 & 0 \\
\hline 11290 & ORF1ab1 & $\mathrm{T}$ & $\langle *\rangle$ & S3675DEL & 0 & 0 & 0 & 0 & 0 & 0 & 0 \\
\hline 11291 & ORF1ab1 & $\mathrm{G}$ & $\langle *\rangle$ & G3676DEL & 0 & 0 & 0 & 0 & 0 & 0 & 0 \\
\hline 11292 & ORF1ab1 & $\mathrm{G}$ & $\langle *\rangle$ & G3676DEL & 0 & 0 & 0 & 0 & 0 & 0 & 0 \\
\hline 11293 & ORF1ab1 & $\mathrm{T}$ & $\langle *\rangle$ & G3676DEL & 0 & 0 & 0 & 0 & 0 & 0 & 0 \\
\hline 11294 & ORF1ab1 & $T$ & $\langle *\rangle$ & F3677DEL & 0 & 0 & 0 & 0 & 0 & 0 & 0 \\
\hline 11295 & ORF1ab1 & $T$ & $\langle *\rangle$ & F3677DEL & 0 & 0 & 0 & 0 & 0 & 0 & 0 \\
\hline 11296 & ORF1ab1 & $\mathrm{T}$ & $\langle *\rangle$ & F3677DEL & 0 & 0 & 0 & 0 & 0 & 0 & 0 \\
\hline 21614 & $\mathrm{~S}$ & $\mathrm{C}$ & $\mathrm{T}$ & L18F & 0 & 0 & 0 & 0 & 0 & 0 & 0.338 \\
\hline 21621 & $\mathrm{~S}$ & $\mathrm{C}$ & A & T20N & 0 & 0 & 0 & 0 & 0.0006 & 0.0026 & 0 \\
\hline 21638 & $\mathrm{~S}$ & $C$ & $T$ & P26S & 0 & 0 & 0 & 0 & 0 & 0 & 0 \\
\hline 21974 & $\mathrm{~S}$ & $\mathrm{G}$ & $T$ & D138Y & 0 & 0 & 0 & 0 & 0.0026 & 0.0025 & 0.0017 \\
\hline 22132 & $\mathrm{~S}$ & $\mathrm{G}$ & $\mathrm{T}$ & R190S & 0 & 0 & 0 & 0 & 0.0012 & 0.0021 & 0.0028 \\
\hline 22812 & $\mathrm{~S}$ & $\mathrm{~A}$ & $C$ & K417T & 0 & 0 & 0 & 0 & 0 & 0 & 0 \\
\hline 23012 & $\mathrm{~S}$ & G & A & E484K & 0 & 0 & 0 & 0 & 0 & 0 & 0 \\
\hline 23063 & $S$ & $A$ & $T$ & $\mathrm{~N} 501 \mathrm{Y}$ & 0 & 0 & 0 & 0 & 0.0029 & 0.0038 & 0.0044 \\
\hline 23403 & $\mathrm{~S}$ & A & $\mathrm{G}$ & D614G & 0.9972 & 1 & 0.9969 & 1 & 0.9969 & 0.9977 & 0.9981 \\
\hline 23525 & $\mathrm{~S}$ & C & $\mathrm{T}$ & $\mathrm{H} 655 \mathrm{Y}$ & 0 & 0 & 0 & 0 & 0 & 0 & 0 \\
\hline 24642 & $S$ & C & $T$ & T1027I & 0 & 0 & 0 & 0 & 0 & 0 & 0 \\
\hline 25912 & ORF3a & $\mathrm{G}$ & $T$ & G174C & 0 & 0 & 0 & 0 & 0.0015 & 0.0009 & 0.0013 \\
\hline 28167 & ORF8 & $\mathrm{G}$ & $A$ & E92K & 0 & 0.0006 & 0 & 0 & 0 & 0 & 0.0016 \\
\hline 28512 & $\mathrm{~N}$ & $C$ & $\mathrm{G}$ & P80R & 0 & 0 & 0 & 0 & 0 & 0 & 0 \\
\hline
\end{tabular}


medRxiv preprint doi: https://doi.org/10.1101/2021.03.18.21253604; this version posted March 26, 2021. The copyright holder for this preprint (which was not certified by peer review) is the author/funder, who has granted medRxiv a license to display the preprint in perpetuity.

\section{References:}

1. Bolger AM, Lohse M, \& Usadel B (2014) Trimmomatic: a flexible trimmer for Illumina sequence data. Bioinformatics 30(15):2114-2120.

2. Heng $L$ (2013) Aligning sequence reads, clone sequences and assembly contigs with BWA-MEM. arXiv:1303.3997.

3. Li H \& Durbin R (2009) Fast and accurate short read alignment with Burrows-Wheeler transform. Bioinformatics 25(14):1754-1760. 